\title{
Development of "Balai Ilmu" Blog Based on Blended Learning to Support Drama Learning in High School Class XI Students
}

\author{
Rini Purnama Sari \\ Universitas Negeri Surabaya \\ Surabaya, Indonesia \\ rinipurnamasari68@gmail.com
}

\author{
Prima Vidya Asteria \\ Universitas Negeri Surabaya \\ Surabaya, Indonesia \\ primaasteria@unesa.ac.id
}

\begin{abstract}
This study utilizes blogs to support drama learning in classroom. Blogs can be used as a means to facilitate learning. Researchers develop IT-based teaching materials, namely the blog "Balai Ilmu", it is to support drama learning in classroom. During this time the drama learning process only uses textbooks and drama scripts so that this research develops blogs as e-learning. Then, collaborates with face-to-face learning which is then called blended learning based learning. This study uses research and development methods adapted from Sugiyono's theory. With the blog "Balai Ilmu" which contains material about drama, it can make the learning process more effective because the meetings that should be used for the provision of material can be replaced with the giving of tasks or drama plays so as to facilitate teachers and students in drama learning.
\end{abstract}

\section{Keywords—blog, blended learning, dram}

\section{INTRODUCTION}

The learning process is a system. Thus, the achievement of learning standards in improving the quality of education can be started from the analysis of each component that shapes and influences the learning process [1]. One component that needs to be considered is learning devices or commonly referred to as teaching materials. Some learning tools commonly used in schools are syllabi, student books, Student Activity Sheets, Learning Implementation Plans, learning outcome tests, and learning media.

Teaching material is one instrument that influences student learning outcomes. It is because teaching material is a learning material that is used as a reference in facilitating the learning process carried out by teachers and students. In other words, learning material is anything that can be used to improve students' knowledge and experience in learning.

In its implementation in schools, there are still many schools that use teaching materials in the form of textbooks. The teacher only teaches reading methods and uses less innovative media and learning resources in the learning process, so that students feel bored and eventually they are difficult to understand the teaching materials. For that reason, the researchers are trying to develop a new learning that is by mixing conventional learning with online learning commonly called Blended Learning.

Blended learning is combining conventional learning (only face to face) with learning using information and communication technology. Through blended learning, learning can be developed according to student learning needs.
Thus, face-to-face classes are used to engage students in interactive experiences while online classes provide educators with participants. Online classes use multimedia content that is rich in knowledge at all times, and anywhere as long as internet access is available. In online learning, some teaching materials will be included in a blog called "Balai Ilmu" which can be accessed by students, so that even without being in the school students can get knowledge.

Seeing the amount of materials in learning Indonesian, the researcher will only focus on drama learning so that the results achieved can be maximized. In addition, drama learning is also very necessary to train students in expression, confidence, and courage. Thus, in face-to-face learning students will be explained in terms of drama, the elements contained in the drama, and some theories about drama. Meanwhile, in online learning students will be referred to some good drama performance videos, how to move the body and face, as well as a brief description of the drama.

According to Mariyani [4], teaching materials are all forms of materials used to assist teachers / instructors in carrying out teaching and learning activities in class. The question material can be in the form of written material or unwritten material. Teaching materials are information, tools and texts that are needed by the teacher/infrastructure for planning and reviewing the implementation of learning (National Center for Vocational Education Research Ltd / National Center for Competency Bassed Training). Teaching materials are a set of materials that are systematically arranged both written and not so as to create an environment/atmosphere that allows students to learn. Meanwhile, according to Widodo and Jasmadi [3], teaching materials are a set of learning tools or tools that contain learning material, methods, boundaries, and ways to evaluate. Which are designed systematically and attractively in order to achieve the expected goals, namely achieving competencies or subcompetencies with all its complexity.

For that reason, based on some understanding above, teaching materials are a set of tools to help teacher in learning process. Teaching materials can be in the form of written or unwritten material that is arranged systematically.

Teachers are required to be diligent and creative in finding and collecting materials needed in learning. The success of a teacher in carrying out learning depends on insight, knowledge, understanding, and level of creativity in managing teaching materials. The more complete the teaching material collected 
and the broader the teacher's insight and understanding of the material, the better the learning will be carried out [8].

This blog media was first popularized by Blogger.com, which is owned by Pyra Labs before being acquired by Google around the end of 2002. Since then, there have been many open source applications intended for the development of the bloggers. Blog is an abbreviation of "Web Log" is a web application in the form of writings or images commonly referred to as a post or posting on a general web page such as a blog. These writings are often loaded in reverse order, usually the most recent content is then followed by a longer content. Websites like this blog are usually accessible to all internet users in accordance with the topic or destination that is being sought by visitors from search engines [9].

According to Rouf and Sopyan in Santosa [6]), blogs are an online site serves as a journal / diary for someone. Jovan in Santosa [6]) added that blogs are "a personal diary, a daily pulpit, a collective space, a political soapbox, a breaking-news outlet, a collection of links, one's own private thoughts, and memos to the world." Graham in Santosa [6]) also stated that making a blog is not difficult because it only requires a simple understanding of accessing the internet, as easy as making and sending e-mail. Creating a blog does not require an understanding of programming languages or complicated programming syntax because everything has been done by the system. All you have to do is write and publish it directly. Blogs with various types and variations of features have attracted many people to use them in their classrooms.

Then According to Sjukur [7] based on the opinions of several experts, Blended learning is a combination of traditional learning and electronic learning environments or blended learning. Combining aspects of blended learning such as webbased learning, video streaming, synchronus communication and asynchronus with traditional "face-to-face" learning.

Besides, there are other terms of Blended Learning that are often used, including blended e-Learning and hybrid learning. Those terms contain the same meaning, namely combination, mixing or combination of learning. To more easily understand the differences in those terms, Mainnen in Prayitno [9] said "blended learning has several alternative names, namely mixed learning, hybrid learning, blended e-learning and melted learning (Finnish)". It is because the learning model uses a mixture of blended e-learning more on learning than face-toface or residential and visiting tutorials, so the author uses the term blended e-learning. In addition, Heinze (in Wendhie, without years) also believes "a better term for 'blended learning' is blended e-learning'."

Drama is a literary form that can stimulate passion and delight the players and viewers so that they are very popular with society. This form is supported by traditions from time immemorial that are closely attached to the culture of the local community. Besides, being easily adapted to be played and enjoyed by people of all ages, drama is very high in educational value [14].

According to Morris in Tarigan [5] the word drama comes from Greek; he stressed from the verb dran which means "to do, to act, or to do". Thus, in terms of its etymology, drama prioritizes action, motion, which is the essence of the nature of every drama that is drama. So it is no surprise that Moulton said that "drama is a life that is shown by motion" (life presented in action).

\section{METHOD}

This research uses a descriptive-qualitative approach, so the results of the research to be presented are dominated by words or sentence. Learning tools in the form of material about drama that can be accessed by students through blogs. The blog is named balaiilmupendidikan.blogspot.com which contains material related to drama. In addition, learning is also done face-to-face. Face-to-face learning is filled with discussion and practice drama. This research is a combination of face-to-face learning with e-learning. Face-to-face learning can be done in the classroom or outside the classroom with material, discussion, assignment and drama practice. In addition, face-toface learning is collaborated with blogs balaiilmupendidikan.blogspot.com which contains drama material that can be accessed by students through the internet. Furthermore, the process of development, quality and implementation of teaching materials was examined. This research uses Research and Development $(R \& D)$ method [2].

\section{RESULTS AND DISCUSSION}

Development of the teaching materials for the blog "Balai Ilmu" as to support drama learning in class XI is based on a problem. There are still many school schools that have not used innovative and interesting teaching materials, media and learning resources for students. For this reason, the researchers developed the blog "Balai Ilmu" as a new step intended to support the learning process of drama in class XI. The development of this "Balai Ilmu" blog teaching material has been developed and refined in stages, the steps of development are potential and problems, data collection, product design, design validation, design revision, usage test, product revision, and product spreader. The results of the research on the development of the blog "Balai Ilmu" are as follows:

\section{Potential and problem}

The researchers analysis the potential and problem in the learning process, that is the lack of inappropriate learning tools that are less innovative and less attractive to students. One such learning tool is teaching material. Therefore, researchers develop teaching materials that utilize IT-based technology, namely blogs.

\section{Data collection}

Researchers collected data in the form of learning resources that developed in several schools. Then, the researchers found out how the ins and outs of blogs and blended learning based learning. This is done in order to prepare the product manufacturing process.

\section{Product design}

After the required data has been collected, the researchers start to make the product. The first thing the researchers did was creating a blog called "Balai Ilmu", designing a blog, creating blog content in the form of video scrubs, articles, drama 
performances and videos related to drama. Then, the production of the product is continued by filling the material into the blog.

\section{Design validation and revision}

Validation is done by blogger design and material experts' after the blog product "Balai Ilmu" is ready to be used. This validation includes expert design validation and expert material validation. First, design expert validation. The product design that is ready to be used is validated by experts, namely Mr. Muh Ariffudin Islam S.Sn, M.Sn. The researcher first displays the product that has been made to the design expert, then the media expert is asked to fill out an assessment questionnaire and provide suggestions and responses for product improvement. Based on the responses and suggestions from the design experts, the blog "Balai Ilmu" was revised to distinguish fonts for titles and texts and tidy up or classify content to make it look neater. According to design expert calculations, the "Balai Ilmu" blog based on blended learning as a supporter of the XI grade high school students' learning drama is said to be good. Second, expert material validation. Products that have been validated by the design expert are then revised. After being revised according to the expert's suggestions and responses the design is then displayed to the material expert. Then the material experts were asked to fill out an assessment questionnaire and provide suggestions and responses for product improvement. Based on suggestions and responses from expert material on blog products "Balai Ilmu" was revised regarding the need to see blogs on YouTube as inspiration, the need for variations between images, writing, films and others. Furthermore, the Blended Learning aspects that are still lacking. According to the calculation of material experts, the blog "Balai Ilmu" based on blended learning to support drama learning of the eleventh grade high school students is said to be good.

\section{Product trials and revisions}

After the product design and materials have been validated by experts, the researchers conducted a trial of product use. The trial conducted is a limited trial so that the product is tested for several high school students in class XI. This trial was conducted for 4 class XI students. The trial starts with blended learning based drama learning that combines online and conventional meetings. For online meetings, students are asked to read the material in the blog at their home. Then, at a conventional meeting students were given a little review of the material contained in the blog. After that, the researchers posttest the students. There are two types of post test questions, multiple choice and description. The results show that the average post-test score of students is 92.5 which includes complete and the average score of students' description is 80 which is also classified as complete. Seeing the results of the post-test students can conclude that with the teaching materials the blog "Balai Ilmu" based on Blended Learning is effective to support drama learning in high school students of class XI. In addition to post-test, the researcher also asked students to fill out an assessment questionnaire about the blog "Balai Ilmu" to support of learning the class XI drama. The results show that the blog "Balai Ilmu" is very interesting for students with an average value of $83 \%$ which means it is very valid.

\section{Product dissemination}

After the product has been tested, the product begins to be disseminated through seminars, websites, Instagram, online and other social media.

\section{CONCLUSION}

Teaching materials are one of the instruments that influence student learning outcomes. It is because teaching materials are a learning material that is used as a reference in facilitating the learning process carried out by teachers and students. In its implementation in schools, there are still many schools that use teaching materials in the form of textbooks and the teacher only teaches reading methods and uses less innovative media and learning resources in the learning process, so that students feel bored and eventually they cannot catch anything in the learning. For this reason, the researchers are trying to develop a new learning that is by mixing conventional learning with online learning commonly called Blended Learning. According to Rouf and Sopyan (in Santosa [6]), blogs are an online page (site) that functions as a journal / diary for someone.

According to Sjukur [7] based on the opinions of several experts, Blended Learning is a combination of traditional learning and electronic learning environments or Blended Learning. Combining aspects of Blended Learning (electronic format) such as web-based learning, video streaming, synchronous communication and asynchronus with traditional "face to face" learning. The research method used in this research is Research and Development (R \& D) research method which is adapted from Sugiyono's theory. Several steps of development in this research are potential and problems, data collection, product design, design validation, design revision, product usage testing, product revision, and product dissemination.

From the research conducted by researchers, it has been found that according to the validation of the design experts and blog material experts used, it is good to be used to support learning drama in high school students of class XI. Then, the trial has been used for class XI high school students by conducting a post-test which consists of two types, multiple choice and description.

After holding a post-test for some high school students of class XI, the results showed that the average score of students on multiple choice questions was 92.5 which included complete and the average score of the students' description was 80 which was also classified as complete.

In addition, to doing the post-test, the researcher also asked students to fill out an assessment questionnaire in the form of the attractiveness of the blog "Balai Ilmu" for students who showed an average score of $83 \%$ which meant it was very valid. From the results above, it can be concluded that the blog "Balai Ilmu" based on Blended Learning is good to be used to support drama learning for high school students in class XI. 


\section{REFERENCES}

[1] V. Sanjaya, Education Process Oriented Learning Strategies. Jakarta: Prenamedia Group, 2006.

[2] Sugiyono, Education Research Methods of quantitative research, qualitative and R \&D. Bandung: Alfabeta, 2017.

[3] C. Widodo,\& Jasmadi, Guide to Developing Competency-Based Teaching Materials. Jakarta: PT Elex Media Komputindo, 2008.

[4] S. Mariyani, Development of Teaching Materials Based on Interactive Multimedia Computerized Accounting Courses, (Case Study: Myob Accounting 17 in the Banking Module), 2012.

[5] M. H. Santosa, "Utilization of Blogs (Online Journal) in Writing Learning". Online:

(http://www.researchgate.net/publication/268371339_Pemanfaat

BBlog_Jurnal_Online_dalam_Pembelajaran_menulis),

Downloaded March 132018
[6] S. B. Sjukur, "Effect of Blended Learning on Learning Motivation and Student Learning Outcomes at Smk Level". Journal Vocational Education, Vol 2, Number 3, November 2012

[7] Trianto, Integrated Learning Model: Concept, Strategy, and Implementation in Education Unit Level Curriculum (KTSP). Jakarta: Bumi Aksara, 2010.

[8] W. Prayitno, "Implementation of Blended Learning in Learning in Primary and Secondary Education". Online:

(https://www.google.co.id/search?client=ucweb-bbookmark\&q=journals+implementation+blended + learning + in + lear ning + on + education + basics + middlemiddle $=$ journal + implementatio $\underline{\mathrm{n}+\text { basic }+ \text { intermediate }+\mathrm{in}+\text { learning }+ \text { on }+ \text { education }+ \text { basic }+ \text { intermedi }}$ ate \&aqs=mobile-gws-lite), 
